Article

\title{
Citizens' Food Habit Behavior and Food Waste Consequences during the First COVID-19 Lockdown in Spain
}

\author{
Berta Vidal-Mones ${ }^{1}$ (D), Héctor Barco ${ }^{2}$, Raquel Diaz-Ruiz ${ }^{3}$ and Maria-Angeles Fernandez-Zamudio ${ }^{4, * \mathbb{D}}$ \\ 1 Center for Agro-Food Economy and Development (CREDA-UPC-IRTA), Castelldefels, \\ 08860 Barcelona, Spain; berta.vidal@upc.edu \\ 2 Enraíza Derechos, 20012 San Sebastian, Spain; h.barco@enraizaderechos.org \\ 3 Fundación Espigoladors, 08810 Barcelona, Spain; raquel@espigoladors.com \\ 4 Centro para el Desarrollo de la Agricultura Sostenible, Instituto Valenciano de Investigaciones Agrarias, \\ Moncada, 46113 Valencia, Spain \\ * Correspondence: fernandez_marzam@gva.es
}

Citation: Vidal-Mones, B.; Barco, H.; Diaz-Ruiz, R.; Fernandez-Zamudio, M.-A. Citizens' Food Habit Behavior and Food Waste Consequences during the First COVID-19 Lockdown in Spain. Sustainability 2021, 13, 3381 https://doi.org/10.3390/su13063381

Academic Editor: Marc A. Rosen

Received: 19 November 2020

Accepted: 15 March 2021

Published: 18 March 2021

Publisher's Note: MDPI stays neutral with regard to jurisdictional claims in published maps and institutional affiliations.

Copyright: (c) 2021 by the authors. Licensee MDPI, Basel, Switzerland. This article is an open access article distributed under the terms and conditions of the Creative Commons Attribution (CC BY) license (https:// creativecommons.org/licenses/by/ $4.0 /)$.

\begin{abstract}
During the first COVID-19 wave in Spain, confining the population at home was seen as an effective way to prevent the disease from spreading. This limited mobility affected citizens' routines at homes because it influenced their life habits, including food management. The main objective of this paper was to understand citizens' food waste (FW) behavior during the first COVID-19 lockdown in Spain by understanding related food practices that could have influenced FW generation. An online survey was conducted from 14 May to 11 June, 2020; 6293 valid responses were collected and analyzed, and $95 \%$ of the participants declared not wasting more food than usual. On average, they reported wasting $234 \mathrm{~g}$ per household per week, which equals $88 \mathrm{~g}$ per capita. We found significant differences in the reported FW generation between participants regarding their age, gender, household composition, and employment status due to COVID-19. In addition, food-related behaviors such as buying more food than usual due to fear or anxiety, storing more food than before the lockdown, and improvising when buying groceries seemed to affect the FW reported by the participants. The paper ends by comparing the conclusions drawn by different works conducted in other countries for a similar purpose.
\end{abstract}

Keywords: food waste; food habits; food management; food consumption; coronavirus; confinement; pandemic; household sector

\section{Introduction}

The detection of coronavirus SARS-CoV-2 at the end of 2019, its rapid expansion worldwide, and its serious consequences [1] led the scientific community to ask lots of questions. Mainly healthcare-related questions about a disease that the World Health Organization (WHO) declared a pandemic on 11 March, 2020 were logically stressed. According to Laguna et al. [2], early in April 2020, 7496 publications that mentioned the terms COVID/coronavirus appeared on the Web of Knowledge. Most of them were related to the biology of the disease and how it medically behaved. Works on the theme have not stopped increasing and have extended to all sorts of areas such as social sciences, among others.

These studies not only cover the impact of the current global pandemic, but also the effects of the measures taken to address COVID-19, which are modifying the day-to-day life of citizens worldwide. These changes in citizens' lifestyles and food habits could affect the normal functioning of the agri-food supply chain (FSC). Indeed it is well reported that the current food system's sustainability is threatened by food loss and waste due to its environmental, social, and economic impacts [3]. According to Gustavsson et al. [4], about one-third of the food produced worldwide for human consumption is lost or wasted along the FSC. 
Despite several strategies and goals having been developed and implemented to prevent current food waste (FW) levels [5,6], the effect of COVID-19 could modify both FW generation along the entire chain and the perspective to achieve a global reduction.

FW estimates differ among studies for several reasons, including the definition of FW and the quantification methodologies utilized [7-12]. Lack of comparability increases the difficulty of creating a rigorous diagnostic about FW in different territories. Furthermore, the majority of FW studies are currently based on indirect measurements, especially from similar bibliographic sources [8]. Hence, the current poor reliability of FW information hampers the creation of a baseline to be halved by 2030 [13] to meet international objectives [5], which are also included in European regulation [14].

The household (HH) sector is the most widely studied stage of the FSC on different territorial scales and includes many different ways of measuring FW, including direct measurements [8,12]. The majority of FW measurements in $\mathrm{HHs}$ are taken in medium-high income countries [8], where HH FW covers the largest share of total FW. In the European Union, the FUSIONS Project estimated that $53 \%$ of all FW is generated by HHs [15], where each European $\mathrm{HH}$ wastes about $0.53 \mathrm{~kg}$ of food per week [16]. Nevertheless, there is considerable variability between different studies of European FW annual per capita estimates, with a range between $76 \mathrm{~kg} / \mathrm{p} / \mathrm{y}$ and $92 \mathrm{~kg} / \mathrm{p} / \mathrm{y}$ [9].

This variation between annual per capita FW estimates in HHs is also evident nationally in the European Union. The estimate for Greece [17] indicates a total of $98.9 \mathrm{~kg} / \mathrm{p} / \mathrm{y}$, where $30.1 \%$ of the overall $\mathrm{FW}$ is avoidable, which means $29.8 \mathrm{~kg} / \mathrm{p} / \mathrm{y}$. Smaller quantities are shown for Hungary, where the total FW generated in HHs is $68.04 \mathrm{~kg} / \mathrm{p} / \mathrm{y}$ and $48.7 \%$ is avoidable, which implies $33.14 \mathrm{~kg} / \mathrm{p} / \mathrm{y}$. The avoidable FW in HHs has also been quantified in Finland [18], with smaller $(23 \mathrm{~kg} / \mathrm{p} / \mathrm{y})$ numbers than in Hungary and Greece.

The analysis of the main FW studies in the European Union [12] concludes that the estimations in the HHs sector range from 21 to $139 \mathrm{~kg} / \mathrm{p} / \mathrm{y}$, and some studies only focus on avoidable FW, whereas others cover total FW. These differences are also identified in similar works for European and non-European countries, where the HH FW estimates vary from 5 to over $100 \mathrm{~kg} / \mathrm{p} / \mathrm{y}$. These divergences are based not only on the definition of FW, but also on the method used to generate these figures. In fact, some studies $[19,20]$ cast doubt on the reliability of questionnaires to know FW measurements because respondents tend to underestimate their own estimates. These positive illusion biases or other forms of cognitive dissonance were also named the "attitude-behavior gap" [21]. Nevertheless, the use of questionnaires is suitable for collecting background information about $\mathrm{HH}$ profiles, citizens' food habits, and perceptions of and attitudes towards FW [22], which are key aspects to gaining a broader picture of the FW problem. HH FW is generally produced mainly by consumer food-related behaviors, which are associated with purchasing discipline, waste prevention habits, and materialism values [23]. Some specific examples are, firstly, lack of planning grocery shopping and making meal plans; secondly, purchasing too much food due to large pack sizes and discount products; and thirdly, practices that reduce products ${ }^{\prime}$ shelf lives due to wrong storage conditions when purchasing groceries and storing them at home [24].

The unprecedented alteration due to COVID-19 in our daily lives brought about changes in citizens' food habits. It can be assumed that these alterations can lead to changed FW behavior. The present work analyzed Spanish HHs' food management performance in general and perception of FW in particular during the first COVID-19 lockdown. Before the lockdown period, the Spanish government reported that each Spanish HH waste was approximately $1.47 \mathrm{~kg}$ per week [25]. FW differs among food categories, where fruit and vegetables are those associated with the highest FW throughout the FSC and also with $\mathrm{HH}$. In Spanish HHs, FW represents 30\% of all HH FW, followed by cereals with 20\% [26].

The lockdown in Spain during the first COVID-19 wave, which was one of the strictest in Europe, involved severe mobility restrictions, particularly after publishing the State of Alarm Decree, which came into force on 14 March 2020, and continued until 21 June 2020. 
Changes in the Spanish population's diet during the first lockdown were analyzed, among others, by Pérez-Rodrigo et al. [27]. Some works confirmed that some favorable aspects emerged during this period, such as more population groups eating more fruit and legumes [28]. Opposing behaviors tended to be perceived because, although part of the population improved its diet during the lockdown and put the lockdown to good use to prepare healthier meals, another part increased its intake of alcohol, fizzy drinks, snacks, and sweet foods [29] or ultraprocessed meals [30].

The present article offers the results of a survey conducted with Spanish HHs during the first COVID-19 home lockdown. The general study approach is similar to that employed in Tunisia [31], the UK [32-34], the Netherlands [35], and Italy [36], whose central point was to better understand the HH FW situation during the study period. Thus, the main objective of this paper was to understand citizens' food habit behavior according to three research questions: (1) Did citizens' food habits change during the lockdown? (2) did households change their FW generation behavior due to the lockdown? and (3) did the lockdown and its consequences on $\mathrm{HH}$ food habits make citizens acquire food learning?

\section{Materials and Methods}

\subsection{FW Concept}

In this study, food waste (FW) is understood as the perceived amount of edible parts of foods thrown away by the participants in their HH during the first COVID-19 lockdown in Spain.

\subsection{Survey and Its Distribution}

To answer these questions, a survey was designed to address HHs. It was conducted from 14 May to 11 June, 2020. This period coincided with the end of the strictest lockdown period that took place in Spain during the first COVID-19 wave, when citizen mobility was extremely restricted. This survey addressed people normally in charge of shopping and/or cooking at home nationwide.

A 36-question survey was used, which lasted roughly $10 \mathrm{~min}$. When it was designed, it was comparable to other European teams that had analyzed FW to determine our questions in order to compare how different populations behaved and their influence on FW. The survey was sent via social networks (Twitter, Facebook, and especially WhatsApp), and also by mass emailing, using institutional contact networks, similar groups, and consumer associations. This involved non-probabilistic and convenience sampling. After reviewing the received responses and checking whether there were any duplications or anomalous data, 6293 valid responses were grouped. The respondents' profiles are offered in Table 1. The sample does not represent the Spanish population. We obtained answers from more women, which is often the case with viral surveys about food, and from older citizens. The other variables cannot be compared because the COVID-19 situation altered the previous status and there are still no data available to make comparisons.

\subsection{Survey Structure}

This survey was arranged in five groups of questions. First, it asked about certain usual habits at home and any changes taking place compared to the situation before COVID19. The participants were specifically asked about the way they purchased food, how they preserved it and cooked it, dates when food was eaten, and how leftovers were managed. The second group of questions was about how the FW produced at home was perceived. Third, there were questions about changes in FW before the lockdown by distinguishing by food typology. Fourth, the participants were asked about the reasons why FW took place, that is, whether they thought they threw away more or less food, or about the same amount, during the lockdown than before. Finally, an open-ended question was included for the participants to indicate whether they had acquired any food management learning during the lockdown. The specific questions included in this survey are found in Table A3 of the Appendix A. 
Table 1. The sample's socio-demographic characteristics.

\begin{tabular}{|c|c|c|c|c|}
\hline \multirow[b]{2}{*}{ Socio-Demographic Category } & \multicolumn{2}{|c|}{$\begin{array}{l}\text { The Sample's } \\
\text { Profile } 1\end{array}$} & \multicolumn{2}{|c|}{$\begin{array}{l}\text { General Population } \\
\text { in Spain } 2020^{2}\end{array}$} \\
\hline & No. & $\%$ & No. & $\%$ \\
\hline \multicolumn{5}{|l|}{ Gender: } \\
\hline Female & 4694 & 74.6 & $23,255,590$ & 51.0 \\
\hline Male & 1544 & 24.5 & $24,195,205$ & 49.0 \\
\hline Not declared & 55 & 0.9 & & \\
\hline \multicolumn{5}{|l|}{ Age (years): } \\
\hline Under 20 & 23 & 0.4 & $9,691,683$ & 20.4 \\
\hline $21-40$ & 1730 & 27.5 & $11,466,009$ & 24.2 \\
\hline $41-60$ & 3781 & 60.1 & $14,788,304$ & 31.2 \\
\hline Over 60 & 759 & 12.1 & $11,504,799$ & 24.2 \\
\hline Mean age (years): & 48 & & 43.55 & \\
\hline \multicolumn{5}{|l|}{ Number of people per $\mathrm{HH}$ : } \\
\hline 1 & 680 & 10.8 & $4,829,600$ & 25.8 \\
\hline 2 & 1907 & 30.3 & $5,690,058$ & 30.4 \\
\hline 3 & 1532 & 24.3 & $3,848,456$ & 20.6 \\
\hline 4 & 1697 & 27 & $3,228,079$ & 17.3 \\
\hline 5 or more & 477 & 7.6 & $1,096,086$ & 5.9 \\
\hline No. HHs with people aged under 14 years: & 2145 & 34 & & \\
\hline \multicolumn{5}{|l|}{ Occupational situation: } \\
\hline Work & 4471 & 68.6 & $19,176,900$ & 83.7 \\
\hline Unemployed & 2008 & 30.8 & $3,722,900$ & 16.3 \\
\hline \multicolumn{5}{|l|}{ Employment status due to the COVID-19 } \\
\hline \multicolumn{5}{|l|}{ lockdown } \\
\hline Employed: teleworking & 2535 & 4.3 & & \\
\hline Employed: on-site physical work & 1941 & 30.8 & & \\
\hline Unemployed and incomeless & 265 & 4.2 & & \\
\hline Employed: furlough scheme-COVID-19 & 293 & 4.7 & & \\
\hline Retirement pension & 760 & 12.1 & & \\
\hline Other & 499 & 7.9 & & \\
\hline \multicolumn{5}{|l|}{ Has anyone at home had COVID-19?: } \\
\hline No & 5988 & 91.8 & & \\
\hline Yes & 509 & 7.8 & & \\
\hline
\end{tabular}

\subsection{Data Analysis}

The study sample was characterized through a descriptive analysis. The FW per capita variable was computed by dividing the household food waste "HH FW" by the declared number of "HH inhabitants." Analyses of variance (t-tests and ANOVA) were carried out to assess the differences among groups of respondents. We first tested whether there was significant difference in the HH FW and per capita FW among age groups, gender, number of inhabitants per $\mathrm{HH}, \mathrm{HH}$ with children, and employment status during the lockdown. Then specific changes in food habits (buying more food due to anxiety or fear, storing more food than usual, planning groceries less, and using shopping lists) were evaluated. Finally, changes in specific food habit practices were also included in the analysis. Consecutively, post hoc tests (Games-Howell test) were conducted to assess which categories significantly differed from each other on HH FW and FW per capita for variables with more than

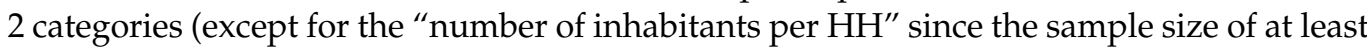
one of the categories was too low to run the test). Statistical analyses were performed with the SPSS v.27 software. The open-ended question was analyzed through a content analysis.

\section{Results}

The results of the study are in the following order. Firstly, a description of the changes in food habits during the lockdown compared to the period before it is provided. Secondly, the impact assessment of the lockdown on the generated HH and per capita FW is de- 
scribed. Lastly, the most relevant learnings acquired and reflections made on food habits by respondents during the lockdown are presented.

\subsection{Food Habits during the Lockdown}

The participants generally reported no changes in their food habits, as shown in Table 1. However, a series of habits appeared in relation to buying food, which is worth stressing. First, and as expected, food shopping frequency lowered due to restricted mobility $(75.3 \%)$. More than half $(58.8 \%)$ the respondents stated buying more food locally, and $13.4 \%$ reported buying more food over the Internet. Moreover, $45.4 \%$ indicated having stored more food than usual at home, whereas $31.4 \%$ shopped more due to fear or anxiety. Only $2.7 \%$ stated wasting more food than usual, whereas the rest believed they had not.

As for usual HH food management practices, we checked changes that had taken place during the lockdown compared to the pre-COVID-19 period (Table 2). Although most people indicated having used shopping lists, $27.2 \%$ of the participants stated that this habit increased during the lockdown. Moreover, $9.1 \%$ confirmed that they no longer improvised while shopping, which presumably meant that the participants planned their shopping more. Using a freezer to conserve food properly was indicated by $11.5 \%$, whereas $8.3 \%$ adapted the rations they would eat. One habit emerged: that of preparing more creative recipes with leftovers, which $22.5 \%$ of the surveyed people stated doing more than before.

Table 2. Food habit changes in household during the first wave of the COVID-19 lockdown.

\begin{tabular}{|c|c|c|c|}
\hline \multirow[b]{2}{*}{ Food Habits } & \multicolumn{3}{|c|}{$\%$} \\
\hline & No & Yes & NA \\
\hline Have you bought more food than usual out of fear or anxiety? & 67.6 & 31.4 & 1.0 \\
\hline Do you eat more food than usual? & 74.8 & 24.1 & 1.1 \\
\hline Have you stored more food than usual? & 53.5 & 45.4 & 1.1 \\
\hline Are you wasting more food than usual? & 95.8 & 2.7 & 1.6 \\
\hline Have you changed your diet? & 74.5 & 24.1 & 1.3 \\
\hline Do you buy more food products online? & 85.2 & 13.4 & 1.4 \\
\hline Do you go shopping more often? & 24.1 & 75.3 & 0.6 \\
\hline Do you buy more often in neighborhood stores? & 40.5 & 58.8 & 0.7 \\
\hline
\end{tabular}

Note: NA (not applicable); HH (household).

Another outstanding aspect was that $43.3 \%$ of all those surveyed indicated eating expired food both during and before the lockdown, which poses a health risk. Other practices may downplay citizen performance in terms of environmental awareness during the pandemic, as $10.40 \%$ of the participants reported neither recycling nor separating leftovers. Additionally, $1.1 \%$ of respondents recognized that they did not reuse leftovers, even before the lockdown, whereas $4.3 \%$ reported the opposite.

\subsection{Impact on $\mathrm{HH} F W$}

As we were interested in learning whether people knew how much FW they generated per week at home, we asked them if they could estimate it. Approximately $58 \%$ of respondents said they could. Then we asked those who answered yes to this question if they could specify how much HH FW they generated per week in grams. We stressed that they should not include inedible food parts such as skin, bones, fruit stones, or shells. The respondents reported generating $234.72 \mathrm{~g}$ (SD: \pm 420.28) per HH per week on average, which equals $88.42 \mathrm{~g}$ (SD: \pm 154.57$)$ per capita. This average reflects the distribution of answers as $21.9 \%$ reporting wasting $0 \mathrm{~g}$ and $80.1 \%$ of the sample not wasting more than 300 g per HH per week.

Table 3 shows the changes that took place in HHs during the lockdown according to the FW levels per food typology. Of them all, the majority indicated that they wasted the same amount as before the lockdown, and $31.5 \%$ stated that they never ate readymade meals. The three food types that the participants stated wasting more than before the lockdown were bread $(7.5 \%)$, fruit $(7.6 \%)$, and vegetables $(4.5 \%)$, which also coincided with 
the food types that a higher percentage of people reported throwing away smaller amounts of during the lockdown (Table 4).

Table 3. Changes in household food management habits during the lockdown due to COVID-19.

\begin{tabular}{|c|c|c|c|c|c|}
\hline \multirow[b]{2}{*}{ Food Habits } & \multicolumn{5}{|c|}{$\%$} \\
\hline & 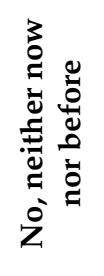 & 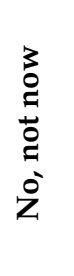 & 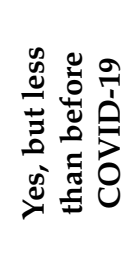 & 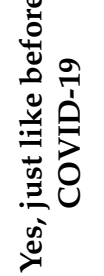 & 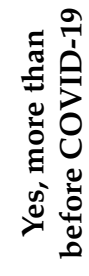 \\
\hline $\begin{array}{l}\text { When I go shopping I end up improvising and } \\
\text { taking products that I had not planned. }\end{array}$ & 27.5 & 9.1 & 13.4 & 43.9 & 6.1 \\
\hline I go grocery shopping with a list of what I need. & 9.5 & 0.4 & 2.7 & 60.3 & 27.2 \\
\hline $\begin{array}{l}\text { I try to cook the products that are going to expire } \\
\text { or spoil first. }\end{array}$ & 2.0 & 0.2 & 0.3 & 89.3 & 7.7 \\
\hline $\begin{array}{l}\text { I use the freezer to better preserve both what I buy } \\
\text { and what is left over from what I cook. }\end{array}$ & 4.4 & 0.4 & 1.0 & 82.8 & 11.5 \\
\hline $\begin{array}{l}\text { When storing food, I take into account its best } \\
\text { before date and the manufacturer's storage } \\
\text { instructions. }\end{array}$ & 6.1 & 0.2 & 0.3 & 90.2 & 3.3 \\
\hline $\begin{array}{l}\text { I check the fridge to know the state of the food I } \\
\text { keep in it. }\end{array}$ & 3.7 & 0.1 & 0.5 & 86.6 & 9.1 \\
\hline I organize food to know what should be eaten first. & 10.1 & 0.3 & 0.5 & 79.9 & 9.3 \\
\hline $\begin{array}{l}\text { I make different creative recipes to take advantage } \\
\text { of both leftovers and all edible food parts. }\end{array}$ & 19.2 & 1.1 & 0.8 & 56.5 & 22.5 \\
\hline $\begin{array}{l}\text { I adjust cooking portions to what we are really } \\
\text { going to eat. }\end{array}$ & 13.3 & 0.9 & 2.2 & 75.2 & 8.3 \\
\hline If there are leftovers, they are used at another time. & 1.1 & 0.2 & 0.5 & 93.9 & 4.3 \\
\hline $\begin{array}{l}\text { If the occasion arises, I first use the food that has } \\
\text { passed its best before date. }\end{array}$ & 22.6 & 0.8 & 1.7 & 72.8 & 2.1 \\
\hline $\begin{array}{l}\text { If the occasion arises, I first use the food that has } \\
\text { passed its use-by date. }\end{array}$ & 52.2 & 1.9 & 1.3 & 43.3 & 1.4 \\
\hline I recycle and sort food waste carefully. & 10.4 & 1.5 & 3.3 & 81.2 & 3.5 \\
\hline
\end{tabular}

Note: $\%$ adds up to $100 \%$ within rows.

Table 4. Changes in household food waste during the lockdown due to COVID-19 according to food typologies.

\begin{tabular}{lllll}
\hline \multirow{2}{*}{ Food Typology } & \multicolumn{3}{c}{$\%$} \\
\cline { 2 - 5 } & Less than before & Same as before & $\begin{array}{l}\text { More than } \\
\text { before }\end{array}$ & $\begin{array}{l}\text { We Do Not Eat } \\
\text { This Food }\end{array}$ \\
\hline Vegetables & 22.5 & 72.3 & 4.5 & 0.7 \\
Fruits & 22.8 & 69.3 & 7.6 & 0.3 \\
Dairy & 18.1 & 78.4 & 2.0 & 1.4 \\
Eggs & 16.9 & 80.3 & 2.0 & 0.8 \\
Fish & 16.5 & 78.7 & 1.7 & 3.1 \\
Meat & 16.1 & 78.5 & 2.2 & 3.2 \\
Pasta and rice & 14.8 & 82.5 & 2.1 & 0.6 \\
Biscuits & 14.0 & 70.9 & 3.9 & 11.2 \\
Bread & 18.7 & 71.4 & 7.5 & 2.4 \\
Precooked meals & 10.9 & 56.2 & 1.4 & 31.5 \\
Drinks & 12.6 & 76.1 & 2.4 & 8.9 \\
\hline
\end{tabular}

Note: $\%$ adds up to $100 \%$ within rows.

Moreover, people were asked whether they thought that their HH had generated more or less FW than in other neighboring homes. The answer was overwhelming: 81.6\% 
indicated that they wasted less food or much less food than other neighbors, whereas only $2.3 \%$ of the respondents stated wasting more or much more.

After obtaining the general HH FW characteristics and the most wasted food types, we asked the participants whether they made an effort to prevent FW. About $70 \%$ of them reported acting normally, whereas $18.2 \%$ made efforts to avoid throwing food away during the lockdown. In any case, $6.9 \%$ alleged that they could not afford to throw food away.

We found that the people who stated throwing more food away than before the lockdown were a minority group and represented only $3 \%$ of the whole sample. Most indicated that the main reason for generating more FW was staying at home longer than usual, followed by buying more food than before. The latter connects with the next reason for storing more food at home. Fourth, they attributed FW to the difficulty of calculating the food that their home needed.

Those who stated producing the same FW as always represented $70.1 \%$ of the whole sample. One of their main reasons was that products had expired. Other main reasons were not having many leftovers and it not being worthwhile to keep leftovers, or not being careful with food management.

Finally, some participants stated that they threw away less food during the lockdown (20.1\% of the whole sample), and $6.7 \%$ produced much less FW. In both cases, the main reasons for generating less FW during this period were using all food to avoid shopping, putting leftovers to better use, cooking more accurately, and facing fewer unexpected events.

Regarding how some socio-economic- and food-related factors affected the FW of both $\mathrm{HH}$ and per capita levels, the following results were observed (see Table 5). For the socio-economic $\mathrm{HH}$ characteristics a significant effect appeared for the FW between age ranges at both $\mathrm{HH}$ and per capita levels. The total HH FW increased with age and the same happened at the per capita level. However, this tendency seemed to differ among participants older than 65 years, who wasted significantly less food than the other age categories, except for the youngest one. See Table A2 in the Appendix A. Second, sex also had a significant effect on HH FW and per capita FW, where males reported higher FW levels than females and those not declaring their gender. Third, the number of $\mathrm{HH}$ inhabitants had a significant effect on the $\mathrm{HH}$ FW, which increased with the number of $\mathrm{HH}$ inhabitants, as could be expected. However, when considering FW per capita, we found an inverse relationship: The more inhabitants, the less FW. Fourth, on average the participants with children under 16 perceived significantly larger FW amounts per $\mathrm{HH}$ than those with no children. This difference was not significant in FW per capita. Fifth, the employment situation that stemmed from the COVID-19 lockdown had a significant effect on the FW at both the $\mathrm{HH}$ level and per capita level. Participants that indicated being "employed: furlough scheme-COVID-19" reported the highest HH FW levels, followed by those indicated as being "employed: teleworking" and "employed: on-site physical work." Participants who reported the lowest FW generation per $\mathrm{HH}$ were those receiving a "retirement pension" $(\mathrm{M}=177.71 \mathrm{~g}$. $\mathrm{SD}=332.12)$, together with those who were "unemployed and incomeless." The effect on the FW per capita was similar to that on HH FW but with different figures (see Table 5). However, according to the post hoc tests (see Table A2 in the Appendix A) significant differences in the HH FW and FW per capita were observed among those who were "employed: teleworking," who were associated with higher FW than those in a "retirement pension" and "other." In addition, participants who were "employed: on-site physical work" seemed to significantly perceive higher $\mathrm{HH}$ FW than those with a "retirement pension." Those who were "employed: teleworking" were associated with significantly higher FW per capita than those who declared "other" employment status. 
Table 5. Mean and standard deviation of household food waste and per capita food waste per category.

\begin{tabular}{|c|c|c|c|c|c|c|c|c|}
\hline \multirow{2}{*}{ Variables } & \multirow{2}{*}{ Variables and Categories } & \multirow{2}{*}{$\mathbf{N}$} & \multicolumn{3}{|l|}{ HH FW } & \multicolumn{3}{|c|}{ FW Capita } \\
\hline & & & Mean (g) & SD (g) & $p$-Value & Mean (g) & SD (g) & $p$-Value \\
\hline Total & & 3663 & 234.72 & 420.28 & & 88.42 & 154.57 & \\
\hline \multirow{5}{*}{ Age } & $18-25$ & 50 & 149.58 & 209.88 & \multirow{5}{*}{0.000} & 58.28 & 75.98 & \multirow{5}{*}{0.000} \\
\hline & $26-35$ & 413 & 227.97 & 312.83 & & 111.65 & 164.20 & \\
\hline & $36-50$ & 1465 & 271.55 & 505.25 & & 91.02 & 159.45 & \\
\hline & $51-65$ & 1560 & 218.97 & 376.53 & & 84.37 & 154.58 & \\
\hline & Over 65 & 175 & 107.05 & 151.41 & & 56.51 & 81.18 & \\
\hline \multirow{3}{*}{ Gender } & Female & 2709 & 213.46 & 380.13 & \multirow{3}{*}{0.000} & 80.66 & 143.47 & \multirow{3}{*}{0.000} \\
\hline & Male & 929 & 294.40 & 514.81 & & 109.83 & 181.61 & \\
\hline & Not declared & 15 & 206.67 & 285.75 & & 96.22 & 105.65 & \\
\hline \multirow{9}{*}{ Inhabitants } & 1 & 432 & 138.16 & 238.91 & \multirow{9}{*}{0.000} & 138.16 & 238.91 & \multirow{9}{*}{0.00} \\
\hline & 2 & 1131 & 180.73 & 299.53 & & 90.36 & 149.76 & \\
\hline & 3 & 896 & 248.34 & 399.80 & & 82.78 & 133.27 & \\
\hline & 4 & 944 & 297.51 & 529.05 & & 74.38 & 132.26 & \\
\hline & 5 & 204 & 354.60 & 649.65 & & 70.92 & 129.93 & \\
\hline & 6 & 37 & 368.30 & 423.17 & & 61.38 & 70.53 & \\
\hline & 7 & 13 & 419.54 & 723.09 & & 59.93 & 103.30 & \\
\hline & 8 & 1 & 100.00 & & & 12.50 & & \\
\hline & 10 & 5 & 161.00 & 206.41 & & 16.10 & 20.64 & \\
\hline \multirow{2}{*}{ Kids under 16} & No & 2502 & 194.22 & 307.86 & \multirow{2}{*}{0.000} & 88.01 & 152.78 & \multirow[b]{2}{*}{0.369} \\
\hline & Yes & 1107 & 323.95 & 577.31 & & 88.11 & 157.11 & \\
\hline \multirow{6}{*}{$\begin{array}{l}\text { Employment status due to } \\
\text { COVID-19 }\end{array}$} & Employed: teleworking & 1483 & 261.97 & 498.24 & \multirow{6}{*}{0.001} & 95.03 & 168.70 & \multirow{6}{*}{0.034} \\
\hline & Employed: on-site physical work & 1133 & 230.36 & 328.75 & & 90.36 & 147.30 & \\
\hline & Unemployed and incomeless & 149 & 190.41 & 449.19 & & 64.81 & 121.43 & \\
\hline & Employed: furlough scheme-COVID-19 & 151 & 285.84 & 596.24 & & $\begin{array}{l}04.01 \\
95.63\end{array}$ & $\begin{array}{l}121.43 \\
156.64\end{array}$ & \\
\hline & Retirement pension & 458 & 177.71 & 332.12 & & 77.68 & 157.88 & \\
\hline & Other & 289 & 198.46 & 259.09 & & 72.32 & 105.61 & \\
\hline \multirow{2}{*}{$\begin{array}{l}\text { Buy more food than usual out of } \\
\text { fear or anxiety }\end{array}$} & No & 2549 & 210.00 & 374.68 & \multirow{2}{*}{0.000} & 79.96 & 135.58 & \multirow[b]{2}{*}{0.000} \\
\hline & Yes & 1076 & 289.78 & 495.07 & & 107.69 & 189.10 & \\
\hline \multirow{2}{*}{ Store more food than usual } & No & 2024 & 208.06 & 405.11 & \multirow{2}{*}{0.000} & 78.53 & 147.57 & \multirow{2}{*}{0.000} \\
\hline & Yes & 1596 & 268.13 & 434.25 & & 100.95 & 161.75 & \\
\hline & No, neither now nor before & 1131 & 185.07 & 408.96 & & 68.24 & 139.11 & \\
\hline & No, not now & 334 & 232.26 & 477.62 & & 86.56 & 155.16 & \\
\hline End up improvising and taking & Yes, but less than before COVID-19 & 496 & 275.11 & 403.91 & 0.000 & 103.51 & 142.17 & 0.000 \\
\hline & Yes, just like before COVID-19 & 1503 & 243.86 & 376.14 & & 93.10 & 150.76 & \\
\hline & Yes, more than before COVID-19 & 199 & 351.31 & 644.30 & & 133.26 & 250.83 & \\
\hline
\end{tabular}

Standard deviation (SD); significance test (sign. test)

Significance tests: Variables with more than 2 categories were analyzed by ANOVA, whereas variables with 2 categories were analyzed by $t$-tests (t). Mean difference is significant at $p$-value: 0.05 level. 
Regarding food-related factors, the participants who bought more food due to anxiety seemed to perceive significantly larger FW amounts per $\mathrm{HH}$ and per capita level than participants who did not. Moreover, HHs that reported storing more food than usual declared significantly higher HH FW than those that did not. The same significant effect was observed on the FW per capita. Furthermore, there was a significant effect of the FW on "ending up improvising and taking products that I had not planned" both at the $\mathrm{HH}$ level and the per capita level. Those who stated not improvising, neither during the lockdown nor before, reported significantly lower FW amounts than the rest of participants, except for those who answering "No, not now" (see Table A2 in the Appendix A). The rest of the variables regarding food habits did not show any specific pattern (see Table A1 in Appendix A).

\subsection{Learning Acquired by the Population}

The survey participants answered the following open-ended question: "During the lockdown time, did you think about food management? We would appreciate it if you could share with us some of your reflections or acquired learning."

Although some respondents reported that they did not learn about or reflect on anything related to food management at home, many others did. The main reflection themes are shown in Figure 1.

\section{Main reflection and learning shared by the study participants}

Spending more time at home allowed people practising more cooking, better meal and shopping planning and improving their diet quality

Reflections on food waste management

Learning on the importance of the local primary sector, food values and failures of the conventional food system

Thoughts on the gender roles and balances at home

Figure 1. Main topics of reflections and learning expressed by the study participants during the COVID-19 lockdown.

3.3.1. Spending More Time at Home Allowed People Practicing More Cooking, Better Meal and Shopping Planning and Improving Their Diet Quality

Most respondents reflected on the good practices they followed during the lockdown, which were determined mainly by spending more time at home, the quality of their diet, and the different marketing channels they used during the lockdown.

The majority of people's answers indicated that they had to reduce their usual shopping frequency due to government restrictions. This made people improve how they planned groceries, meals, and menus, and they spent more time cooking, organizing their food storage, and improving food conservation practices. However, some people admitted to resorting to compulsive shopping at the beginning of the lockdown due to anxiety and fear. Most felt ashamed about this. They also attempted to be more hygienic and cleaner than before the lockdown to avoid infection.

Regarding diet, most respondents reported having followed a healthier diet during the lockdown than they normally did, and having eaten fewer processed foods and better prepared meals instead. Regarding the amount of food, almost half the respondents stated having eaten more during the lockdown and practicing a less healthy style due to lack of physical activity. Finally, a minority ate more processed foods (e.g., chocolate, chips, alcohol) to feel better and to counterbalance anxiety. 


\subsubsection{Reflections on Food Waste Management}

Reducing FW at home was a common reflection made by many respondents. This is normal because the main issue throughout the survey was FW. The main reasons for some respondents reducing FW were spending more time cooking and eating at home, and cooking new recipes with leftovers. In particular, people sharing apartments learned to prevent FW by sharing meals. In addition, people with pets reported preventing FW by feeding their dogs in cities and chickens in the countryside.

3.3.3. Learning on the Importance of the Local Primary Sector, Food Values, and Failures of the Conventional Food System

Apart from the particular changes to food habits that the participants wished to share, some reflected on broader issues related to the food system, for instance, reflections on the importance of producers and our current dependence (as a society) on the globalized food trade. This could be one of the reasons why people reported buying more in local shops or starting to buy directly from producers during the lockdown. Moreover, those who expressed the latter really appreciated the efforts made by some producers to deliver food to their homes. Others reflected on imbalances between the stakeholders involved in different FSCs, mostly in regard to abusive price margins, mainly in retail. The increased prices of healthy foods such as fruit and vegetables in supermarkets was an example of these reflections. These experiences made some people reflect on the need to promote food sovereignty.

In addition, the people who made efforts to reduce their environmental impacts before the lockdown complained because they felt forced to use more plastic while shopping for groceries for the hygiene reasons imposed by retail. This was another driver for some respondents to highlight the importance of eating more organic, local, and seasonal foods, whose purchase involves much less plastic. Other reasons for supporting organic and local food included the relation between conventional agriculture and its environmental and health impacts. Lastly, many respondents expressed their concerns about the consumerism that our society is based on.

\subsubsection{Thoughts on Gender Roles and Balances at Home}

Some participants also reflected on social and gender balances at home. In this group, some men expressed that being home during the lockdown made them realize how much work being a "housewife" involves. At the same time, some women stated that their husband and children engaged more in food-related tasks, such as cooking or buying groceries, during the lockdown. Finally, some families indicated that they appreciated eating together at home, which was something they could not normally do due to their busy routines.

\subsubsection{Identifying Their Privileges Compared to Other Households}

The lockdown made some people think about COVID-19 and the socio-economic crisis. Many respondents reflected on the importance of being healthy and having proper nutrition habits, along with how the lack of freedom would affect people's mental and physical health. Others learned to appreciate their privileges compared to vulnerable people who depended on food donations.

\subsubsection{Sharing Proposals to Maintain Good Practices after the Lockdown and/or Future}

Some respondents became creative by suggesting different ideas to improve their food habits during "normality" and possible future lockdowns. They wrote about improving food labeling to help consumers make healthier choices and properly preserve foods. Others thought that their houses were not prepared to store enough food for lockdowns. Some people reflected on the impact that their diet has on the environment, and proposed eating less meat. 
Some women worried about the difficulty of balancing their work/life after the lockdown, mainly because they would not find the time to invest in food-/care-related habits after the lockdown. Others seemed quite determined to maintain their acquired habits, as they helped them to eat more healthily and more cheaply than before. Others recommended different apps that helped them to plan their meals and shopping, and provided ideas about how to include leftovers in menus and find offers in food stores.

Other proposals took a collective approach, such as the importance of community gardens for the family or having collective chickens to feed them with organic leftovers and getting free eggs in return, together with their power to create a community, which could help in future lockdowns.

Lastly, some respondents shared ideas to be implemented by public administrations. They expressed the need to facilitate food donations for people in need from both individual donors and supermarkets. Introducing nutrition, healthy food, and FW prevention habits at schools to raise the awareness of future generations and their families was another proposal.

\section{Discussion}

The results obtained from this study fall in line with other similar works conducted in Europe [32-36]. The survey in Spain shows that the majority of respondents confirmed the same FW amount than before the lockdown and COVID-19 times, which was around $69 \%$ of all responses. Nevertheless, $28 \%$ of the respondents thought that they wasted less food during the lockdown period. Similar percentages were found in the Dutch study [35], where the majority also confirmed a similar FW volume than before COVID-19, and 26\% of the total estimated that they wasted less food during lockdown. The latter group of respondents was bigger in the UK study, where 36\% claimed lower FW amounts at the beginning of the lockdown compared to pre-COVID-19 times. In Italy [36], the results highlighted the same feeling of wasting less food during lockdowns. They estimated that they wasted $6 \%$ of all the purchased food compared to $10 \%$ before COVID- 19 .

Similar results appeared beyond the European Union. In Tunisia, a study showed [31] that $89 \%$ of the respondents expressed awareness of this problem during the COVID19 period, which was higher than in pre-pandemic months (71\%). A comparative study between household food habits in the United States and China [38] also confirmed the positive change about food behavior and the valuation of food during the pandemic period, with people throwing away less food. Furthermore, the COVID-19 pandemic has also led to a positive behavioral change regarding food waste in Japan [39] and Qatar [40].

On a global scale, the study conducted by the United Nations (UN) is key. Although more than half of all the respondents came from Western Europe and North America, the study covered 118 countries. Their results also fell in line and outlined the respondents' growing FW concern.

The larger part of the population perceiving less FW than before COVID-19 could be linked with acquiring better food management habits. The more available time spent on food management seems one of the main common drivers in the abovementioned European countries; $28 \%$ of respondents in the Dutch study stated that they cooked more during the lockdown and $21 \%$ reported having more time to cook. This circumstance enabled them to, for example, prepare new meals, or use leftovers or ingredients they had at home. Furthermore, $23 \%$ of the Spanish participants confirmed preparing more creative meals, which rose to $33 \%$ in the UK. Higher percentages were recorded in Italy [36], where this extra available time was taken as an opportunity to rediscover traditional recipes, such as bread (45.5\%), pizzas (65.2\%), and cakes (67.5\%). Outside of Europe, there was an increase in making home-cooked meals more often in the case of the United States and China [41] (62\% and $60 \%$, respectively) and spending more time cooking or eating (48\% and $73 \%$, respectively) while staying at home. This increase was also reported in the cases of Japan [39] and Qatar [40], where 49.20\% were cooking and preparing food much more frequently. In global terms, the UN study [42] shows that $50 \%$ of all the respondents confirmed having more time to cook at home. 
However, it is important to remark that spending more time at home and/or cooking more was not always associated with a lower FW. Changes in employment status due to the COVID-19 lockdown seemed to significantly affect FW. According to our results, participants in a "employed: furlough scheme-COVID-19" situation and those who started teleworking reported the highest mean FW levels during the lockdown among all the employment status categories. However, significant differences were only observed between participants who were teleworking and participants who were in a "retirement pension" situation or those who selected the option "other." The differences between the sample size of the categories analyzed might be a reason for the post hoc test not detecting as significant the differences between the FW reported by the participants in a "employed: furlough scheme-COVID-19" situation and those belonging to the employment categories associated with the lowest FW levels. In the reflections section, some of these people expressed feeling stressed because they were working more hours than usual, along with cooking for the whole family or taking care of children. The same tendency was observed by those people who felt anxiety or fear, and those storing more food than usual during the lockdown. Thus, it would be interesting for future studies to assess how people suffering from any type of mental health issue related was to FW generation during both lockdown situations and their usual pre-COVID-19 lives. It also warns researchers to not assume that FW would be reduced by spending more time at home.

Moreover, decreasing shopping frequency emerged as a parameter that implemented good food management habits in HHs during COVID-19. This reason was highlighted by $54 \%$ of the participants in the UK study [33]. This fact encouraged some good practices, for example, more responsible purchasing by checking the refrigerator before shopping and writing shopping lists. This could also help to avoid improvised and impulse purchases by using some of the apps and websites recommended by the study participants, which helped them to improve their food habits.

Accordingly, $75.3 \%$ of the Spanish participants confirmed buying food less frequently, which was a higher percentage than in the UK (63\%). Nevertheless, these numbers decreased in the Dutch study, where only $36.3 \%$ of the total stated buying food once a week. A total of $63 \%$ of the Italian respondents reported purchasing food once a week during the lockdown, whereas $56 \%$ bought food two to three times a week in previous months. A very different scenario was observed in Tunisia, where $35 \%$ of the respondents claimed that they bought food two to three times per week and 34.5\% went shopping every day during COVID-19. The China and U.S. study [41] reported a substantial change from frequent trips to the store to dramatic increases in online ordering. In the same line, the COVID-19 pandemic has also transformed consumer habits in Qatar [40], with a surge in online grocery shopping.

Having fewer unforeseen situations was another main parameter that seemed to have helped people to feel they had generated less FW at home. Avoiding these types of episodes reduced distortions in planning weekly menus. This situation was brought to light particularly in Spain and the Netherlands.

Nevertheless, it remains unclear whether these good practices will continue after the lockdown period, when mobility restrictions will ease to some extent. Moreover, the diverse casuistry that may arise due to different ways of managing the COVID-19 situation in territories makes it even more difficult to answer this question. A number of participants in the Spanish survey expressed feeling concerned about the possibility of reconciling work with their new food habits acquired during the lockdown period. This ranged from planning menus and shopping to the time spent on preparing healthy meals and creative cooking. Additionally, some companies might implement teleworking more frequently for their employees after the lockdown, which could affect HH FW, as it was associated with a more marked FW perception in our study. WRAP [34] was the only study to have analyzed how these good practices have evolved during confinement. They showed that despite these habits continuing to some degree, a percentage of them diminished as the lockdown progressed and finished, which left much less room for optimism. 
The study in Tunisia [31] showed that increasing awareness about the FW issue is probably associated with loss of economic income and fear of limited food availability. Similar feelings were associated in the U.S. and China [41], with large increases in people worrying about or experiencing food shortages.

This might not be the case for people in a furlough scheme due to COVID-19 in Spain because they stated increased FW during the lockdown. The increased food insecurity reported in Tunisia also emerged in different territories of the world, such as the case of the study in Bangladesh [43], confirming food and nutritional deficiencies among the vulnerable poorest section due to loss of livelihood. This situation was also pointed out by the UN report [42]. Despite the bias due to the majority of respondents coming from developed countries, $8 \%$ of the total sample already depended on food aid and $17 \%$ confirmed receiving support from alternative food channels, such as family or community food production.

A similar consideration could be made for the lessons learned during COVID-19. As WRAP showed [34], the main motivations at the beginning of the lockdown to practice good food habits were related to the fear of going out. These motivations at the end of the lockdown in the UK were linked more with economic savings and self-awareness of wasting food. Furthermore, this economic saving seemed to be the prevalent motivation in developing countries [31,42] for people who kept their jobs.

As some participants pointed out in the Spanish study with the open-ended question about the lessons learned, there are some tools and digital resources, such as websites and apps, that can help them maintain their good food habits after the lockdown ends. Furthermore, some participants provided measures with a more communitarian character. These communitarian proposals could lead them to appreciating food and to reinforcing the links between neighbors and the community. Essentially, this collective work could more easily detect possible vulnerability and food insecurity cases, and could implement a collective response of assistance and support regardless of whether cases occurred during the lockdown or beyond these exceptional situations.

Finally, we inevitably wondered whether similar levels of FW, indicated by the majority of the respondents in the three European countries considered, were actually real or whether they were merely impressions. In the Spanish study, 21.9\% of all the respondents confirmed that they wasted zero kilos per week, and $80.1 \%$ claimed that they wasted less than $300 \mathrm{~g}$ per $\mathrm{HH} /$ week.

Hence, despite the fact that questionnaires are suitable for analyzing FW perceptions, this methodology is not reliable for measuring the real FW generated $[19,20]$ due to the tendency to underestimate. For this reason, Giordano et al. [44] recommended not using questionnaires to assess the real quantities and motives of FW generation because of its positive illusion bias. The use of diaries and waste-sorting analyses are more suitably coupled together, if and when this is possible. Employing both methods is recommended by Giordano et al. [44], given the underestimation also detected with diaries with about $20 \%$ of actual FW quantities.

\section{Limitations and Further Research}

The results of this study should be interpreted by considering its limitations. First of all, the survey is a snapshot of 6293 citizens' perceptions from May and June 2020. This period corresponds to the first COVID-19 wave and the strictest lockdown in Spanish HHs. The situation was unprecedented and made citizens change the routines of their daily lives. The aim of this study was to note these changes. However, COVID-19 has rapidly evolved and is changing citizens' lives every week. For this reason, we cannot ensure that the perceptions and behaviors described in the results are maintained. It is important to acquire this valuable information about this specific time (the first lockdown) to understand future changes and behaviors as regards FW and the population's eating habits.

Secondly, this study employed non-probabilistic sampling despite its large sample. Therefore, the results should not be considered to be representative of the Spanish popula- 
tion. Digital sampling normally overrepresents the population segments that are more used to digital platforms and social networks, and underrepresents other population groups. Nor can we ensure an equal representation of all Spanish territories. Notwithstanding, a sample of more than $6000 \mathrm{HHs}$ is large enough to obtain a general picture of current trends.

Thirdly, as indicated throughout this manuscript, our study does not aim to describe reality, but rather how a group of citizens perceived their behavior. This duality is very important, and even more so for HH FW, because previous research has noted the influence of social desirability on recognizing FW. Future studies should combine qualitative and quantitative assessments at homes to better describe FW and its reasons.

\section{Conclusions}

Valuable conclusions can be drawn about HH food management and FW after conducting a survey about Spanish HHs during the first COVID-19 lockdown. Generally speaking, the population indicated that its habits did not substantially change, but in practice, certain changes were noted. For instance, the fact that people did not shop as frequently as before conditioned them to better plan their shopping and optimize both food storage and conservation, which resulted in more responsible consumption. The fact that citizens shopped more locally or ordered food online could be a chance for producers to more directly access consumers and to reduce the number of intermediaries, which could reinforce their role in the local economy.

The acquired data indicate that the FW observed in the surveyed Spanish HHs was lower than that indicated in other official sources in Spain, according to the Spanish Ministry of Agriculture [25] for pre-COVID-19 periods. We confirmed that this phenomenon did not appear only for Spain, but was also repeated in other studies $[19,44]$. One of the reasons for this may lie in the surveyed group actually being more aware of the FW problem, and it being favored at a time when citizens had more time to reduce FW. Nonetheless, social distance comes into play when internalizing this problem because, as shown for the Spanish case, a group of people can be aware of the FW problem but, in turn, neither feel guilty nor shoulder the responsibility for it, and mostly perceive FW as being caused by others. Additionally, one interesting finding in this study is that spending more time at home was not associated with wasting less food for everyone, especially for the people whose mental health was affected by changes in their employment status due to the COVID-19 lockdown, such as those forming part of furlough schemes or those who started teleworking. Thus, it is recommended that future studies analyze the possible association between mental health and FW during lockdowns.

The learning indicated by the surveyed citizens is particularly interesting. It is during such a serious situation as COVID-19 when humanity reflects profoundly on certain aspects and values that apply to their daily lives. The list of addressed themes was long and they were grouped to identify them more easily. Spending more time at home was stressed because it was invested in improving the population's eating habits. This exceptional situation allows us to also reflect on today's food system, and the need to promote local consumption and seasonal products as a way to support the primary sector and to reduce dependencies on other countries. In some cases, citizens also reflected on gender roles at home, a situation that has evidenced advantages not only for women, but also for men and children engaging in housework.

In short, some positive advances are also expected. Shared reflections were very valuable and the comments made by many participants were extremely creative, but this does not mean they are not feasible. Actions were frequently proposed to help maintain healthy eating habits after the lockdown. The use of apps and other digital tools is expected to continue and is suggested to promote more rational food use. Other initiatives were not as individual, but emerged from society's commitment to meeting shared achievements, such as community gardens where local seeds are exchanged based on responsible consumption, or other proposals, such as neighbors delivering food to disadvantaged groups. These are 
all excellent examples of the power of human solidarity to overcome special times such as today's crisis.

Author Contributions: Conceptualization, M.-A.F.-Z., H.B., R.D.-R. and B.V.-M.; methodology, R.D.-R., B.V.-M., H.B. and M.-A.F.-Z.; formal analysis, R.D.-R., H.B., B.V.-M. and M.-A.F.-Z.; writingoriginal draft preparation, H.B., M.-A.F.-Z., B.V.-M. and R.D.-R.; writing-review and editing, B.V.M., H.B., R.D.-R. and M.-A.F.-Z. All authors have read and agreed to the published version of the manuscript.

Funding: This research received no external funding.

Institutional Review Board Statement: The study was conducted according to the guidelines of the Declaration of Helsinki.

Informed Consent Statement: Participants accepted to participate in the survey in the introduction page.

Data Availability Statement: The primary data from the study are available to other researchers upon request.

Acknowledgments: Thanks very much to the co-founding colleagues of the "Red Sin Desperdicio" (Aintzane Pérez-Ezkurdia, Maria Jesús Casasnovas, Jenny Marín, Iva Miranda-Pires, Rita BeltrãoMartins, Javier Burbano and Cornelia Baur) for their great work in disseminating the survey and providing support and good ideas for this study. We acklowledge the General CAP Agency (Conselleria de Agricultura, Desarrollo Rural, Emergencia Climática y Transición Ecológica, of the Generalitat Valenciana), for their financial support in order to publish this work within the Plan against food waste in the Comunitat Valenciana (BonProfit Plan), a Plan that is co-financed by the ERDF Funds.

Conflicts of Interest: The authors declare no conflict of interest.

\section{Appendix A}

Table A1. Mean and standard deviation of household food waste and per capita food waste per category.

\begin{tabular}{|c|c|c|c|c|c|c|}
\hline & \multirow[t]{2}{*}{ Categories } & \multirow[t]{2}{*}{$\mathbf{N}$} & \multicolumn{2}{|c|}{ HH FW } & \multicolumn{2}{|c|}{ FW Capita } \\
\hline & & & Mean (g) & $\begin{array}{c}\text { Standard } \\
\text { Deviation (g) }\end{array}$ & Mean $(g)$ & $\begin{array}{c}\text { Standard } \\
\text { Deviation (g) }\end{array}$ \\
\hline \multirow{5}{*}{$\begin{array}{l}\text { I try to cook the } \\
\text { products that are } \\
\text { going to expire or } \\
\text { spoil first. }\end{array}$} & No, neither now nor before & 61 & 246.12 & 362.84 & 114.53 & 183.21 \\
\hline & No, not now & 6 & 167.00 & 257.94 & 125.08 & 209.11 \\
\hline & $\begin{array}{l}\text { Yes, but less than before } \\
\text { COVID-19 }\end{array}$ & 11 & 722.73 & 756.76 & 300.76 & 323.83 \\
\hline & Yes, just like before COVID-19 & 3320 & 224.72 & 413.36 & 84.66 & 152.77 \\
\hline & Yes, more than before COVID-19 & 265 & 338.61 & 476.41 & 119.87 & 149.47 \\
\hline \multirow{5}{*}{$\begin{array}{l}\text { I use the freezer to } \\
\text { better preserve } \\
\text { both what I buy } \\
\text { and what is left } \\
\text { over from what I } \\
\text { cook. }\end{array}$} & No, neither now nor before & 162 & 237.83 & 674.68 & 96.24 & 203.89 \\
\hline & No, not now & 13 & 267.00 & 296.67 & 79.71 & 87.59 \\
\hline & $\begin{array}{l}\text { Yes, but less than before } \\
\text { COVID-19 }\end{array}$ & 36 & 295.31 & 392.46 & 133.36 & 220.28 \\
\hline & Yes, just like before COVID-19 & 3052 & 225.79 & 396.59 & 84.47 & 148.94 \\
\hline & Yes, more than before COVID-19 & 400 & 295.04 & 462.61 & 111.59 & 165.91 \\
\hline \multirow{5}{*}{$\begin{array}{l}\text { When storing food, } \\
\text { I take into account } \\
\text { its consumption } \\
\text { date and the } \\
\text { storage instructions } \\
\text { given by the } \\
\text { manufacturer. }\end{array}$} & No, neither now nor before & 177 & 257.98 & 472.39 & 113.64 & 179.75 \\
\hline & No, not now & 4 & 80.00 & 90.92 & 26.67 & 27.08 \\
\hline & $\begin{array}{l}\text { Yes, but less than before } \\
\text { COVID-19 }\end{array}$ & 10 & 482.00 & 630.89 & 164.33 & 208.07 \\
\hline & Yes, just like before COVID-19 & 3363 & 229.73 & 408.93 & 85.95 & 151.79 \\
\hline & Yes, more than before COVID-19 & 109 & 333.88 & 606.94 & 119.04 & 183.65 \\
\hline
\end{tabular}


Table A1. Cont.

\begin{tabular}{|c|c|c|c|c|c|c|}
\hline & \multirow[t]{2}{*}{ Categories } & \multirow[t]{2}{*}{$\mathbf{N}$} & \multicolumn{2}{|c|}{ HH FW } & \multicolumn{2}{|c|}{ FW Capita } \\
\hline & & & Mean (g) & $\begin{array}{c}\text { Standard } \\
\text { Deviation }(g)\end{array}$ & Mean (g) & $\begin{array}{c}\text { Standard } \\
\text { Deviation }(g)\end{array}$ \\
\hline \multirow{5}{*}{$\begin{array}{l}\text { I check the fridge to } \\
\text { know the state of } \\
\text { the food I keep in it. }\end{array}$} & No, neither now nor before & 110 & 225.80 & 433.13 & 92.94 & 131.74 \\
\hline & No, not now & 1 & 1.00 & & 0.50 & \\
\hline & $\begin{array}{l}\text { Yes, but less than before } \\
\text { COVID-19 }\end{array}$ & 20 & 408.80 & 363.51 & 204.99 & 184.04 \\
\hline & Yes, just like before COVID-19 & 3212 & 223.70 & 412.32 & 83.50 & 151.48 \\
\hline & Yes, more than before COVID-19 & 320 & 338.22 & 479.97 & 129.23 & 180.41 \\
\hline \multirow{5}{*}{$\begin{array}{l}\text { I organize food to } \\
\text { know what we } \\
\text { should consume } \\
\text { first. }\end{array}$} & No, neither now nor before & 291 & 244.31 & 319.09 & 109.58 & 159.20 \\
\hline & No, not now & 7 & 246.29 & 352.57 & 64.50 & 87.48 \\
\hline & $\begin{array}{l}\text { Yes, but less than before } \\
\text { COVID-19 }\end{array}$ & 15 & 367.67 & 388.90 & 181.89 & 192.12 \\
\hline & Yes, just like before COVID-19 & 3025 & 222.38 & 416.83 & 82.71 & 150.54 \\
\hline & Yes, more than before COVID-19 & 325 & 334.60 & 512.30 & 118.86 & 179.05 \\
\hline \multirow{5}{*}{$\begin{array}{l}\text { I make different } \\
\text { creative recipes to } \\
\text { take advantage of } \\
\text { both the leftovers } \\
\text { and all the edible } \\
\text { parts of the food. }\end{array}$} & No, neither now nor before & 620 & 278.12 & 583.03 & 113.00 & 213.37 \\
\hline & No, not now & 35 & 294.69 & 266.55 & 117.52 & 107.16 \\
\hline & $\begin{array}{l}\text { Yes, but less than before } \\
\text { COVID-19 }\end{array}$ & 24 & 325.92 & 459.97 & 141.63 & 238.52 \\
\hline & Yes, just like before COVID-19 & 2186 & 192.00 & 312.07 & 70.02 & 108.63 \\
\hline & Yes, more than before COVID-19 & 798 & 312.64 & 508.42 & 116.84 & 193.92 \\
\hline \multirow{5}{*}{$\begin{array}{l}\text { I adjust cooking } \\
\text { portions to what } \\
\text { we are really going } \\
\text { to consume. }\end{array}$} & No, neither now nor before & 415 & 272.85 & 480.27 & 113.81 & 194.09 \\
\hline & No, not now & 27 & 516.30 & 824.82 & 182.90 & 237.66 \\
\hline & $\begin{array}{l}\text { Yes, but less than before } \\
\text { COVID-19 }\end{array}$ & 77 & 295.00 & 465.23 & 101.97 & 150.21 \\
\hline & Yes, just like before COVID-19 & 2817 & 211.34 & 371.75 & 78.09 & 131.01 \\
\hline & Yes, more than before COVID-19 & 327 & 350.29 & 604.48 & 134.16 & 240.63 \\
\hline \multirow{6}{*}{$\begin{array}{l}\text { If we have leftovers, } \\
\text { we use them at } \\
\text { another time. }\end{array}$} & No, neither now nor before & 26 & 552.62 & 1043.38 & 190.26 & 288.29 \\
\hline & No, not now & 5 & 265.40 & 429.60 & 116.65 & 216.59 \\
\hline & $\begin{array}{l}\text { Yes, but less than before } \\
\text { COVID-19 }\end{array}$ & 16 & 818.88 & 765.12 & 282.10 & 233.88 \\
\hline & Yes, just like before COVID-19 & 3467 & 222.84 & 398.54 & 83.82 & 147.88 \\
\hline & Yes, more than before COVID-19 & 149 & 391.90 & 565.49 & 155.97 & 217.25 \\
\hline & Total & 3663 & 234.72 & 420.28 & 88.42 & 154.57 \\
\hline
\end{tabular}

Table A2. Post hoc comparisons of household FW and per capita FW between categories of variables after ANOVA test.

\begin{tabular}{|c|c|c|c|c|c|c|c|c|}
\hline & \multicolumn{4}{|c|}{ HH FW } & \multicolumn{4}{|c|}{ FW Capita } \\
\hline & \multicolumn{4}{|c|}{ Games-Howell $p$-Value } & \multicolumn{4}{|c|}{ Games-Howell $p$-Value } \\
\hline & $18-25$ & $26-35$ & $36-50$ & $51-65$ & $18-25$ & $26-35$ & $36-50$ & $51-65$ \\
\hline \multicolumn{9}{|l|}{$18-25$} \\
\hline $26-35$ & 0.142 & & & & 0.001 & & & \\
\hline $36-50$ & 0.003 & 0.200 & & & 0.046 & 0.156 & & \\
\hline $51-65$ & 0.184 & 0.988 & 0.011 & & 0.165 & 0.021 & 0.772 & \\
\hline More than 65 & 0.669 & 0.000 & 0.000 & 0.000 & 1.000 & 0.000 & 0.000 & 0.001 \\
\hline
\end{tabular}


Table A2. Cont.

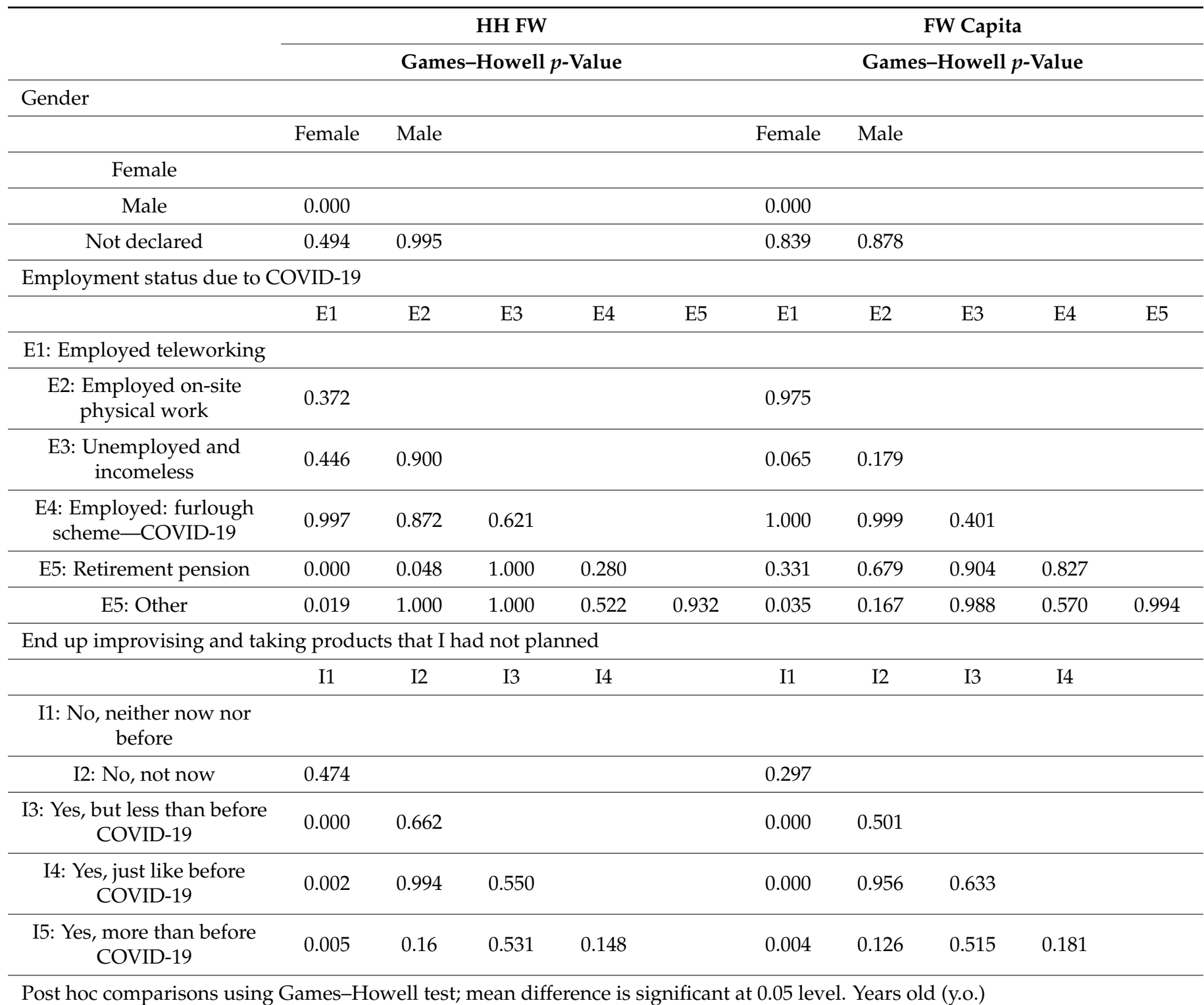

Table A3. Questions in the survey.

Could you indicate whether your household has performed any of the

following actions since the lockdown started?

- Have you bought more food than usual out of fear or anxiety?

- $\quad$ Do you eat more food than usual?

- Have you stored more food than usual?

- $\quad$ Are you wasting more food than usual?

- Have you changed your diet?

- $\mathrm{No}$

- Do you buy more food products online?

- Do you go shopping less often?

- Do you buy more often in neighborhood stores? 
Table A3. Cont.

Could you indicate the changes you have made since the household lockdown?

- I go grocery shopping with a list of what I need.

- When I go shopping I end up improvising and taking products that I had not planned.

- I Iry to cook the products that are going to expire or spoil first.

- I use the freezer to better preserve both what I buy and what is left over from what I cook.

- When storing food, I take into account its consumption date and the storage instructions given by the manufacturer.

- I check the fridge to know the state of the food I keep in it.

- I organize the food to know what we should consume first.

- I make different creative recipes to take advantage of both the leftovers and all the edible parts of the food.

- I adjust cooking portions to what we are really going to consume.

- If the occasion arises, I consume food that has passed its best before date.

- If the occasion arises, I consume food that has passed its use-by date.

- If we have leftovers, we use them at another time.

- We recycle and sort food waste carefully.

Would you be able to estimate the amount of food that is thrown away Yes

for different reasons in your household every week? No

What is the amount of food that is thrown away for different reasons in your household every week?

Yes, just like before COVID-19

Yes, more than before COVID-19

Yes, but less than before COVID-19

No, not now

No, neither now nor before

Considering the following food products during the COVID-19

lockdown, have you ended up throwing more or less of these products

in the trash?

- Fresh or frozen vegetables

- $\quad$ Fruit

- $\quad$ Milk and dairy (yogurt, cheese, etc.)

Less than before

- Eggs

Same

- Fish

More than before

- Meat

We do not eat this product

- Pasta and rice

- $\quad$ Cakes, pastries, biscuits

- Bread

- Other ready-to-eat meals

- Drinks

Do you think you waste more or less than the average families in Spain?

(Much more than the average/More than the average/Same as the average/Less than the average/Much less than the average)

During this lockdown period due to COVID-19, does your household throw away/waste more or less food than before?

(Much more than before/More than before/Same/Less than before/Much less than before)

We act as we always have.

Yes, we waste less food because we do not want to go shopping.

During the confinement, due to restricted mobility to go shopping, do you make more effort in not wasting food?

Yes, we realize that some people are suffering a lot nowadays, so we act amore consciously.

We cannot afford to waste food.

During the confinement, have you reflected on food management? We would be pleased if you could share some of your thoughts with us. 
Table A3. Cont.

\begin{tabular}{|c|c|}
\hline Please indicate your gender. & Male/Female/Not declared \\
\hline \multicolumn{2}{|l|}{ How old are you? } \\
\hline \multicolumn{2}{|l|}{$\begin{array}{l}\text { With how many people do you share your household, including } \\
\text { yourself? }\end{array}$} \\
\hline \multicolumn{2}{|l|}{ How many people aged under 14 years old live in your household? } \\
\hline $\begin{array}{l}\text { In the last few weeks, have you or somebody in your household lost } \\
\text { their job or earned less salary? }\end{array}$ & (Yes/No) \\
\hline $\begin{array}{l}\text { In the last few weeks, have you or somebody in your household been } \\
\text { sick or had to isolate due to COVID-19? }\end{array}$ & (Yes/No) \\
\hline What is your employment status during confinement? & $\begin{array}{l}\text { Jobless and incomeless. } \\
\text { I receive a subsidy. } \\
\text { I do the same job, but remotely. } \\
\text { I do my job as usual. } \\
\text { I have been temporarily laid off. } \\
\text { Other (please specify). }\end{array}$ \\
\hline
\end{tabular}

\section{References}

1. Tan, W.; Zhao, X.; Ma, X.; Wang, W.; Niu, P.; Xu, W.; Gao, G.F.; Wu, G. A novel coronavirus genome identified in a cluster of pneumonia cases. China CDC Wkly. 2020, 2, 61-62. [CrossRef]

2. Laguna, L.; Fiszman, S.; Puerta, P.; Chaya, C.; Tárrega, A. The impact of COVID-19 lockdown on food priorities. Results from a preliminary study using social media and an online survey with Spanish consumers. Food Qual. Prefer. 2020, 86. [CrossRef] [PubMed]

3. Food and Agriculture Organization. Food Wastage Footprint: Impacts on Natural Resources (Technical Report); FAO: Rome, Italy, 2013.

4. Gustavsson, J.; Cederberg, C.; Sonesson, U.; Meybeck, A. Global Food Losses and Food Waste-Extent, Causes and Prevention, 1st ed.; FAO: Gothenburg, Sweden, 2011; ISBN 9780786495566.

5. Nations, U. SDG 12. Sustainable Consumption and Production. Available online: https://www.un.org/sustainabledevelopment/ sustainable-consumption-production/ (accessed on 10 September 2020).

6. Food and Agriculture Organization. Reduction, the State of Food and Agriculture 2019. Moving Forward on Food Loss and Waste; FAO: Rome, Italy, 2019.

7. Chaboud, G.; Daviron, B. Food losses and waste: Navigating the inconsistencies. Glob. Food Sec. 2017, 12, 1-7. [CrossRef]

8. Xue, L.; Liu, G.; Parfitt, J.; Liu, X.; Van Herpen, E.; Stenmarck, Å.; O'Connor, C.; Östergren, K.; Cheng, S. Missing Food, Missing Data? A Critical Review of Global Food Losses and Food Waste Data. Environ. Sci. Technol. 2017, 51, 6618-6633. [CrossRef] [PubMed]

9. Corrado, S.; Sala, S. Food waste accounting along global and European food supply chains: State of the art and outlook. Waste Manag. 2018, 79, 120-131. [CrossRef] [PubMed]

10. Corrado, S.; Caldeira, C.; Eriksson, M.; Hanssen, O.J.; Hauser, H.-E.; van Holsteijn, F.; Liu, G.; Östergren, K.; Parry, A.; Secondi, L.; et al. Food waste accounting methodologies: Challenges, opportunities, and further advancements. Glob. Food Sec. 2019, 20, 93-100. [CrossRef]

11. Barco, H.; Oribe-Garcia, I.; Vargas-Viedma, M.V.; Borges, C.E.; Martín, C.; Alonso-Vicario, A. New methodology for facilitating food wastage quantification. Identifying gaps and data inconsistencies. J. Environ. Manag. 2019. [CrossRef] [PubMed]

12. Caldeira, C.; Barco, H.; De Laurentiis, V.; Sala, S. Review of Studies on Food Waste Accounting at Member State Level; Publications Office of the European Union: Luxembourg, Luxembourg, 2019.

13. European Court of Auditors. Combating Food Waste: An Opportunity for the EU to Improve the Resource-Efficiency of the Food Supply Chain; European Court of Auditors: Luxembourg, Luxembourg, 2016; Volume 34.

14. European Parliament. European Parliament Resolution of 15 January 2020 on the European Green Deal (2019/2956(RSP)); European Parliament: Brussels, Belgium, 2020.

15. Tostivint, C.; Östergren, K.; Quested, T.; Soethoudt, J.M.; Stenmarck, A.; Svanes, E.; O'Connor, C. Food Waste Quantification Manual to Monitor Food Waste Amounts and Progression; FUSIONS: Paris, France, 2016.

16. Massoti, M.; Stewart, G.; Close, A.; Setti, M.; Vittuari, M. D4.6-Pan-European Scenarios of Food Waste Levels; FUSIONS: 2019. Available online: https:/ / doi.org/10.18174/498708 (accessed on 15 September 2020).

17. Abeliotis, K.; Lasaridi, K.; Costarelli, V.; Chroni, C. The implications of food waste generation on climate change: The case of Greece. Sustain. Prod. Consum. 2015, 3, 8-14. [CrossRef]

18. Katajajuuri, J.M.; Silvennoinen, K.; Hartikainen, H.; Heikkilä, L.; Reinikainen, A. Food waste in the Finnish food chain. J. Clean. Prod. 2014, 73, 322-329. [CrossRef] 
19. Giordano, C.; Piras, S.; Boschini, M.; Falasconi, L. Are questionnaires a reliable method to measure food waste? A pilot study on Italian households. Br. Food J. 2018, 120. [CrossRef]

20. Van der Werf, P.; Seabrook, J.A.; Gilliland, J.A. Food for thought: Comparing self-reported versus curbside measurements of household food wasting behavior and the predictive capacity of behavioral determinants. Waste Manag. 2020, 60, 322-328. [CrossRef]

21. Vermeir, I.; Verbeke, W. Sustainable food consumption: Exploring the consumer "attitude—Behavioral intention" gap. J. Agric. Environ. Ethics 2006, 19, 169-194. [CrossRef]

22. Koivupuro, H.K.; Hartikainen, H.; Silvennoinen, K.; Katajajuuri, J.M.; Heikintalo, N.; Reinikainen, A.; Jalkanen, L. Influence of socio-demographical, behavioural and attitudinal factors on the amount of avoidable food waste generated in Finnish households. Int. J. Consum. Stud. 2012, 32, 183-191. [CrossRef]

23. Diaz-Ruiz, R.; Costa-Font, M.; Gil, J.M. Moving ahead from food-related behaviours: An alternative approach to understand household food waste generation. J. Clean. Prod. 2018, 172, 1140-1151. [CrossRef]

24. Van Geffen, L.; Van Herpen, E.; Van Trijp, H. Causes \& Determinants of Consumers Food Waste; REFRESH: Wageningen, The Netherlands, 2016; Volume 20.

25. MAGRAMA Panel de Cuantificación del Desperdicio Alimentario en los Hogares Españoles. Available online: https://www. menosdesperdicio.es/definiciones-cifras/panel-de-cuantificaci \{\{ó\}\}n-del-desperdicio-alimentario-en-los-hogares-espa noles (accessed on 15 September 2020).

26. Garcia-Herrero, I.; Hoehn, D.; Margallo, M.; Laso, J.; Bala, A.; Batlle-Bayer, L.; Fullana, P.; Vazquez-Rowe, I.; Gonzalez, M.J.; Durá, M.J.; et al. On the estimation of potential food waste reduction to support sustainable production and consumption policies. Food Policy 2018, 80, 24-38. [CrossRef]

27. Pérez-Rodrigo, C.; Citores, M.G.; Hervás Bárbara, G.; Litago, F.R.; Casis Sáenz, L.; Aranceta-Bartrina, J.; Val, V.A.; López-Sobaler, A.M.; Martínez De Victoria, E.; Ortega, R.M.; et al. Cambios en los hábitos alimentarios durante el periodo de confinamiento por la pandemia COVID-19 en España. Rev. Esp. Nutr. Comunitaria 2020, 26, 28010. [CrossRef]

28. Ruiz-Roso, M.B.; Padilha, P.d.C.; Mantilla-Escalante, D.C.; Ulloa, N.; Brun, P.; Acevedo-Correa, D.; Peres, W.A.F.; Martorell, M.; Aires, M.T.; de Cardoso, L.O.; et al. Covid-19 confinement and changes of adolescent's dietary trends in Italy, Spain, Chile, Colombia and Brazil. Nutrients 2020, 12, 1807. [CrossRef]

29. Scarmozzino, F.; Visioli, F. Covid-19 and the subsequent lockdown modified dietary habits of almost half the population in an Italian sample. Foods 2020, 9, 675. [CrossRef]

30. Ruíz-Roso, M.B.; de Carvalho Padilha, P.; Matilla-Escalante, D.C.; Brun, P.; Ulloa, N.; Acevedo-Correa, D.; Peres, W.A.F.; Martorell, M.; Carrilho, T.R.B.; de Cardoso, L.O.; et al. Changes of physical activity and ultra-processed food consumption in adolescents from different countries during covid-19 pandemic: An observational study. Nutrients 2020, 12, 2289. [CrossRef]

31. Jribi, S.; Ismail, B.H.; Doggui, D.; Debbabi, H. COVID-19 virus outbreak lockdown: What impacts on household food wastage? Environ. Dev. Sustain. 2020, 22, 3939-3955. [CrossRef]

32. WRAP \& Icaro Consulting. Consulting Citizen Responses to the Covid-19 Lockdown-Food Purchasing, Management and Waste; WRAP: Banbury, UK, 2020.

33. WRAP. Food waste and Covid-19—Survey 2: Lockdown Easing; WRAP: Banbury, UK, 2020.

34. WRAP. Food waste and Covid-19-Survey 3; WRAP: Banbury, UK, 2020.

35. Haar van der, S.; Zeinstra, G.; Bos-Brouwers, H.; Janssen, A. COVID-19 and the effects on Dutch consumers' Food Waste Behaviour. 2020. Available online: https://www.wur.nl/en/Research-Results/Research-Institutes/food-biobased-research/ show-fbr/COVID-19-and-the-effects-on-Dutch-consumers-food-waste-behaviour.htm (accessed on 7 September 2020).

36. Principato, L.; Secondi, L. Caring more about food: The unexpected positive effecto of the Covid-19 lockdown on household food management and waste. Socio-Econ. Plan. Sci. 2020. [CrossRef]

37. INE. Instituto Nacional de Estadísticas. Available online: https:/ /www.ine.es/index.htm (accessed on 11 February 2021).

38. Dou, Z.; Stefanovski, D.; Galligan, D.; Lindem, M.; Rozin, P.; Chen, T.; Chao, A. Household Food Dynamics and Food System Resilience Amid the COVID-19 Pandemic: A Cross-National Comparison of China and the United States. Front. Sustain. Food Syst. 2021, 4, e577153. [CrossRef]

39. Qian, K.; Javadi, F.; Hiramatsu, M. Influence of the COVID-19 pandemic on household food waste behavior in Japan. Sustainability 2020, 12, 9942. [CrossRef]

40. Hassen, T.B.; El Bilali, H.; Allahyari, M.S. Impact of covid-19 on food behavior and consumption in qatar. Sustainability 2020, 12, 6973. [CrossRef]

41. Kulkarni, B.N.; Anantharama, V. Repercussions of COVID-19 pandemic on municipal solid waste management: Challenges and opportunities. Sci. Total Environ. 2020, 743. [CrossRef]

42. COVID-19 Pandemic: The Evolving Impact on How People Meet the Food System; UNSCN 2020. Available online: https: / / www.unscn.org/en/news-events / recent-news?idnews=2065 (accessed on 11 February 2021).

43. Shammi, M.; Bodrud-Doza, M.; Towfiqul Islam, A.R.M.; Rahman, M.M. COVID-19 pandemic, socioeconomic crisis and human stress in resource-limited settings: A case from Bangladesh. Heliyon 2020, 8, 341. [CrossRef]

44. Giordano, C.; Alboni, F.; Falasconi, L. Quantities, Determinants, and Awareness of Households' Food Waste in Italy: A Comparison between Diary and Questionnaires Quantities'. Sustainability 2019, 11, 3381. [CrossRef] 